\title{
MAKNA SIMBOLIS BATIK PADA MASYARAKAT JAWA KUNA
}

\author{
Siti Maziyah'1, Mahirta², Sumijati Atmosudiro² \\ 1) Jurusan Sejarah, Fakultas Ilmu Budaya, Universitas Diponegoro, Semarang. \\ email: mazy_muiz@yahoo.com \\ 2) Jurusan Arkeologi, Fakultas Ilmu Budaya, Universitas Gadjah Mada, Yogyakarta
}

\begin{abstract}
This research aims to analyze symbolic meaning of batik in the ancient Javanese society. Next, it is also analyze whether the existence of batik can describe cultures in contemporary society. The research uses historical method in order to obtain field data and facts. Because of the required data consist of inscription which contains of sima area in the Ancient Mataram Kingdom era made approximately in IX-XVM, so those data are collected either from Jakarta National Museum or pada National Library in Jakarta. Then, interpretation is conducted to synthesize any field facts. The final stage is historiography, that is a writing process of any available facts becoming history writing. According to discussion above, it can be concluded that batik motif in the Ancient Javanese society has symbolic meaning and it can be used as communication tools for contemporary society. The Ancient Javanese society realizes that from batik motif, it can be identified the social stratification of society.
\end{abstract}

Keywords : batik motives, inscription, ancient Java, social class

\begin{abstract}
ABSTRAK
Penelitian ini bertujuan untuk menganalisis makna simbolis batik pada masyarakat Jawa Kuna.Kemudian, dianalisis juga tentang apakah melalui keberadaan batik itu dapat mendiskripsikan kebudayaan masyarakat sezaman.Penelitian ini menggunakan metode penelitian sejarah dalam upaya untuk mendapatkan data dan fakta yang ada di lapangan. Mengingat data yang dibutuhkan berupa prasasti yang berisi tentang daerah sima pada masa Kerajaan Mataram Kuna yang dibuat sekitar abad IX-XV M, maka datadata tersebut "digali" di Museum Nasional Jakarta maupun pada Perpustakaan Nasional di Jakarta.Selanjutnya dilakukan interpretasi untuk mensintesiskan segala fakta yang terdapat di lapangan. Langkah terakhir adalah historiografi, yaitu proses penulisan segala fakta yang ada menjadi sebuah tulisan sejarah.Berdasarkan pembahasan di atas, dapat disimpulkan bahwa motif batik pada masyarakat Jawa Kuna itu memiliki makna simbolik dan dapat digunakan sebagai sarana untuk berkomunikasi bagi masyarakat sezaman.Masyarakat Jawa Kuna menyadari bahwa melalui motif-motif batik dapat diketahui stratifikasi sosial masyarakat.
\end{abstract}

Kata kunci: motif batik, prasasti, jawa kuno, kelas social

\section{PENDAHULUAN}

Alasan pemilihan topik pada tulisan ini bertalian dengan studi yang penulis tekuni dalam bidang arkeologi, yaitu epigrafi. Di Indonesia, epigrafi adalah salah satu bagian dalam ilmu arkeologi yang mempelajari tulisan- tulisan kuna pada prasasti dan sumber lain seperti kesusasteraan dan sumber berita asing, untuk merekonstruksi sejarah Indonesia kuna (Puslitbang Arkenas, 2008:193-194; Tim Penyusun Kamus Pusat Pembinaan dan Pengembangan Bahasa, 1996:268). Sumber data pada tulisan ini lebih ditekankan pada 
prasasti. Adapun prasasti itu sendiri merupakan maklumat yang berisi perintah, pernyataan, pujian, atau keputusan yang dikeluarkan oleh seorang raja atau pejabat tinggi suatu negara, sehingga ragam bahasanya resmi (Puslitbang Arkenas, 2008:193). Materi yang digunakan untuk menulis prasasti adalah batu, lempengan logam (emas, perak, atau tembaga), gerabah, batu bata, atau lontar (Boechari,1977:2).

Prasasti pada masa klasik, yaitu pada awal abad Masehi sampai abad XV (Soekmono, 1993:7), terutama yang berasal dari seorang raja, memiliki struktur yang konsisten, dan informasi yang terdapat di dalamnya akurat serta dapat dipercaya. Misalnya tentang sistem pemerintahan, sistem peradilan, sistem kemasyarakatan, sistem ekonomi, sistem keagamaan, dan sistem kesenian (Puslitbang Arkenas, 2008:193). Berdasarkan isi pesannya, prasasti dapat dikategorikan menjadi tujuh sebagai berikut: (1) Prasasti sima; (2) Prasasti Jayapatra atau Jayasong; (3) Prasasti Suddhapattra; (4) Piagam; (5) Prasasti pada nisan; (6) Prasasti angka tahun; dan (7) Prasasti mantra.

Dari ketujuh jenis prasasti di atas, prasasti yang penulis teliti adalah prasasti sima. Prasasti jenis ini sangat unik, karena salah satu bagian di dalam upacara penetapan sima adalah adanya pemberian hadiah (pasek-pasek) kepada para pejabat maupun tamu undangan yang menghadiri dan menjadi saksi dalam upacara penetapan sima itu. Pemberian hadiah itu dimulai dari raja atau pejabat yang mengeluarkan prasasti kemudian baru pejabat-pejabat di bawahnya hingga pejabat desa dan tamu undangan (Prasodjo, 1987:65). Jenis pasek-pasek yang diberikan oleh daerah yang ditetapkan menjadi sima itu berbeda-beda sesuai dengan jenjang atau hierarki jabatan masing-masing pejabat di dalam pemerintahan kerajaan tersebut. Selain berupa emas dan perak dengan berbagai ukuran berat dan bentuk, ternyata kain dengan motif batik menjadi salah satu bagian dari pasekpasek. Menariknya, jenis motif batik itu pun ternyata diberikan kepada para pejabat sesuai dengan hierarki jabatannya. Antara pejabat satu dengan yang lain, motif yang diberikan berbeda. Sedangkan kepada pejabat yang kedudukannya sejajar diberikan motif yang sama. Dengan demikian, motif batik itu memiliki makna di dalam masyarakat Jawa Kuna, antara lain dapat menentukan hierarki jabatan seseorang.

Berdasarkan uraian di atas, permasalahan yang hendak diangkat pada tulisan ini adalah apakah makna simbolis batik pada masyarakat Jawa Kuna? Apakah melalui keberadaan batik itu dapat mendiskripsikan kebudayaan masyarakat sezaman?

\section{METODE PENELITIAN}

Penelitian ini menggunakan metode penelitian sejarah dalam upaya untuk mendapatkan data dan fakta yang ada di lapangan. Langkah pertama pada metode sejarah adalah heuristik atau pengumpulan sumber. Mengingat data yang dibutuhkan berupa prasasti yang berisi tentang daerah sîma pada masa Kerajaan Mataram Kuna yang dibuat sekitar abad IX-XV M, maka data tersebut "digali" di Museum Nasional Jakarta maupun pada Perpustakaan Nasional di Jakarta. Pada dua tempat itu prasasti-prasasti yang dibutuhkan dicari melalui daftar inventarisasi prasasti. Sebelumnya, para peneliti harus mengetahui kata kunci yang harus dicari pada prasasti-prasasti itu, yaitu adanya istilah sima atau swatantra; pasak-pasak atau pasek-pasek; ken (kain) dan wdihan (bebed, jenis kain untuk laki-laki). Tahap kedua 
adalah melakukan kritik sumber, yaitu memilih dan menentukan sumber yang relevan dengan penelitian, serta yang tidak relevan dengan penelitian. Pada tahab ini dilakukan juga penterjemahan sumber untuk mengetahui relevansi data. Selanjutnya dilakukan interpretasi untuk mensintesiskan segala fakta yang terdapat di lapangan. Langkah terakhir adalah historiografi, yaitu proses penulisan segala fakta yang ada menjadi sebuah tulisan sejarah.

\section{HASIL DAN PEMBAHASAN}

\section{Kondisi Masyarakat Jawa Kuna}

Menurut Kamus Antropologi, masyarakat adalah sejumlah manusia dalam arti yang seluas-luasnya dan terikat oleh suatu kebudayaan yang mereka anggap sama (Suyono, Ariyono dan Aminuddin Siregar, 1985:245). Berdasarkan pengertian konsep masyarakat seperti itu, maka yang dimaksud dengan masyarakat Jawa Kuna adalah masyarakat yang terikat oleh kebudayaan yang sama, yaitu kebudayaan Jawa Kuna. Menurut Koentjaraningrat (1990), suatu suku bangsa selalu memiliki ciri khas yang dapat ditunjukkan oleh daerah kebudayaannya maupun oleh ciri khas yang lain berupa bahasa yang digunakan serta kebudayaannya yang khas baik dalam bentuk budaya material, aktivitas, maupun gagasan.

Ciri khas yang paling mudah untuk melihat kebudayaan salah satu suku bangsa adalah dengan mengetahui bahasa yang digunakan. Berdasarkan persebaran bahasa itu pula akan dapat diketahui daerah kebudayannya. Berdasarkan temuan prasasti-prasasti yang berbahasa Jawa Kuna, dapat diketahui bahwa bahasa itu tersebar di daerah Jawa bagian tengah hingga Jawa bagian timur. Adapun berdasarkan pembu- atannya seperti yang tertera pada masing-masing prasasti, prasasti berbahasa Jawa Kuna itu dibuat pada abad VII sampai abad XV (Brandes, 1913; Buchari dan A.S. Wibowo, 1985). Pada kurun waktu itu, di Jawa sedang dalam pengaruh kebudayaan Hindu, oleh karena itu struktur masyarakatnya pun sama seperti pada masyarakat Hindu yang lain, memiliki sistem kasta. Ada pun sistem pemerintahannya adalah kerajaan dengan corak agraris (Poesponegoro, 1993). Dengan demikian maka dapat diketahui bahwa masyarakat Jawa Kuna adalah masyarakat yang menggunakan bahasa Jawa Kuna sebagai alat komunikasinya, yang tersebar di Jawa bagian tengah maupun Jawa bagian timur, hidup pada abad VII-XV, sehingga memiliki tradisi budaya Hindu.

Berdasarkan pengertian di atas, Kamus Antropologi menunjukkan bahwa masyarakat Jawa Kuna adalah masyarakat tradisional. Yaitu masyarakat yang lebih banyak dikuasai oleh adat-istiadat yang lama. Selain itu, berdasarkan informasi-informasi pada prasasti, masyarakat Jawa Kuna juga dapat dikelompokkan sebagai masyarakat pedesaan. Yaitu masyarakat yang warganya terutama hidup dari pertanian tanpa mekanisasi, yang terutama berproduksi untuk konsumsi sendiri ditambah dengan industri rumah tangga untuk terbatas (Suyono, Ariyono dan Aminuddin Siregar, 1985:246-247).

\section{Batik dalam Perspektif Fenomenologi}

Konsep batik mengandung beberapa pengertian, antara lain adalah teknik pembuatannya, motif batik, bahan batik, fungsi batik serta jenis batik berdasarkan pengaruh budayanya. Pada umumnya ketika membahas masalah batik yang didefinisikan adalah pro- 
sesnya pembuatannya. Teknik pembuatan batik dimulai dengan pemilihan kain sebagai bahan dasarnya. Beberapa jenis kain yang dapat digunakan untuk membatik adalah mori, katun, sutra asli, maupun sutra tiruan. Selanjutnya dilakukan proses pembatikan hingga pewarnaan dengan menggunakan pewarna alam.

Batik adalah suatu karya tulis dengan lilin yang digambarkan pada sehelai kain. Lilin yang dimaksud di sini adalah campuran antara parafin, lilin lebah, gondorukem, mata kucing, dan lemak hewan dengan perbandingan tertentu, yang berbeda-beda antara daerah satu dengan daerah lain. lilin ini lazimnya disebut dengan malam. Perbandingan bahan-bahan ini sekaligus merupakan rahasia perusahaan bagi juragan batik, karena hal itu turut menentukan mutu batiknya (Djumena, 1990:2; Hamzuri, 1981:12-14).

Setelah mengalami beberapa proses, yaitu pengambaran motif dengan lilin, pewarnaan, dan menghilangkan lilin dari kain, terbentuk sehelai kain dengan motif tertentu yang siap untuk dipakai. Menurut Susanto (1973:5), membatik adalah menggambar dengan lilin yang berisi motif-motif ornamentatif. Berdasarkan etimologinya, mbatik adalah rangkaian kata mbat dan tik. Mbat dalam bahasa Jawa diartikan sebagai ngembat atau melempar berkali-kali, sedangkan tik berasal dari kata titik. Dengan demikian kata membatik diartikan sebagai melempar titik berkalikali pada sehelai kain. Batik juga disebut sebagai karya tulis, karena aktivitas membatik dikerjakan dengan penuh teliti seperti layaknya orang menulis. Dalam bahasa Jawa Krama Inggil, kata menulis berarti nyerat, dan membatik pun disebut sebagai nyerat. Dengan demikian, suatu kain dapat disebut sebagai batik apabila mengandung dua unsur pokok, yaitu teknik celup rintang yang menggunakan lilin sebagai perintang warna dan pola yang beragam hias khas batik (Djumena, 1990:1; Santosa, 2002:10).

Secara historis nama dan wujud batik telah dikenal sebelum orang Hindu datang di Indonesia pada sekitar tahun 300-400 sesudah Masehi. Kepandaian membatik sebenarnya merupakan salah satu pengetahuan yang dimiliki oleh bangsa Indonesia sejak jaman kuna. Brandes (1889:122-129) mengemukakan bahwa bangsa Indonesia telah memiliki 10 unsur kebudayaan asli ketika mulai berhadapan dengan kebudayaan India. Kesepuluh unsur tersebut adalah pengetahuan tentang wayang, gamelan, metrum, seni tenun dan batik, industri logam, sistem moneter, navigasi, astronomi, pertanian dengan sistem irigasi, dan suatu organisasi pemerintahan.

Batik telah dikenal lama sebagai pakaian adat Jawa. Hal ini dapat dibuktikan dengan adanya motif batik lereng yang dikenakan patung Siwa pada abad IX yang terdapat di Desa Gemuruh Wonosobo dekat Dieng. Adapun motif ceplok terdapat pada pakaian yang dikenakan oleh patung Ganesha dari Candi Banon di kompleks Candi Borobudur (Susanto, 1973: 295). Pendapat lain mengatakan bahwa produk awal batik diperkirakan lahir di kalangan petani pada jaman Kerajaan Mataram Kuna. Karena adanya perhatian khusus dari kraton, maka batik kemudian masuk dalam lingkungan kraton sebagai manifestasi pengabdian rakyat kepada raja. Setelah memasuki lingkungan kraton teknik pembuatan batik semakin disempurnakan baik motif maupun pewarnaannya. Motif-motif batik yang bermutu tinggi kemudian dipersembahkan kepada raja dan keluarganya. Adapun di kalangan rakyat sendiri batik tetap dibuat dengan motif-motif sederhana. Penciptaan motif 
-motif batik oleh para empu di kraton tidak dilakukan dengan sembarangan, tetapi sama dengan proses yang dilakukan dalam pembuatan keris. Pemberian ilham untuk sebuah motif batik biasanya juga dilakukan dengan meditasi dan puasa mutih. Oleh sebab itu, motif batik tertentu hanya digunakan oleh orang-orang golongan tertentu saja, terutama raja beserta keluarga dan kerabatnya yang memiliki gelar kebangsawanan (Maziyah, 2004:63).

Batik memiliki beberapa jenis baik dilihat menurut gaya desain motif, gaya spesifik daerah, penggunaan, maupun teknik pembuatannya. Gaya desain motif merupakan peleburan dari penataan ornamen-ornamen dan pewarnaan yang memiliki nilai estetika, falsafah hidup, dan kealamiahan dari lingkungan tempat batik tersebut tumbuh. Secara garis besar desain batik dibedakan menjadi dua yaitu desain geometris dan desain non geometris. Desain geometris merupakan suatu bentuk integrasi dari garis lurus, segi empat, segi tiga, trapesium, garis paralel, lingkaran, dan diagonal. Desain geometris antara lain dapat ditemui pada motif ceplok, parang, dan lereng. Adapun desain non geometris terdiri dari semen, lung-lungan, buketan, pinggiran, dan desain spesial. Pada hakekatnya desain non geometris ini sebagian besar menyadap dari lingkungan masyarakat setempat yang berupa tumbuh-tumbuhan yang menjalar (lung-lungan) dan bunga-bungaan (buketan), maupun motif-motif binatang yang disamarkan. Adapun ornamen karakteristik dari desain semen adalah meru yang berbentuk gunung yang menggambarkan gunung Mahameru sebagai tempat tinggal para dewa dalam kepercayaan Hindu.

Jenis batik berdasarkan penggunaannya adalah kampuh atau dodot, jarit, bebet, sarung, iket, kemben, serta selendang. Kampuh atau dodot adalah kain panjang yang dipakai sebagai pakaian kebesaran wanita bangsawan dan abdi dalem kraton yang terdiri dari dua helai kain panjang yang dililitkan ujungnya untuk pemakaian. Jarit adalah kain panjang berbentuk empat persegi panjang, digunakan oleh pria maupun wanita dengan cara membebatkannya pada pinggang. Lilitan untuk pria dilakukan dari kiri ke kanan, sedangkan untuk wanita dari kiri ke kanan. Adapun bebet adalah kain panjang untuk laki-laki, seperti sarung tetapi tidak memiliki hiasan tepi. Dipakai dengan dililitkan menutupi pinggang ke bawah dengan dua kali lilitan. Sarung adalah kain panjang yang tepi pada pangkal dan ujungnya dijahit berhubungan, dapat digunakan oleh perempuan atau laki-laki. Iket adalah penutup kepala bagi laki-laki yang terbuat dari kain. Sedangkan kemben adalah kain kecil sebagai penutup dada wanita. Adapun selendang biasanya digunakan sebagai pakaian pelengkap atau untuk digunakan untuk menggendong (Maziyah, 2004:21-23; Djumena, 1990:5182).

Menurut gayanya, batik dibedakan menjadi batik pedalaman dan batik pesisiran. Sedangkan berdasarkan pengaruh kebudayaannya, menurut Doellah (2002) batik dapat dibedakan menjadi batik kraton, batik pengaruh kraton, batik sudagaran, batik petani, batik pengaruh India, batik Belanda, batik Cina, batik Jawa Hokokai, dan batik Indonesia.

Motif-motif batik yang tercipta tersebut memiliki simbol-simbol yang dapat dikomunikasikan dengan masyarakat. Kepercayaan akan dapat terciptanya suasana religius magis dari pancaran batik menjadikan para bangsawan lebih mengutamakan motif batik yang mengandung arti simbolik. Semua itu didukung oleh keyakinan berdasarkan pola pikir mitologis yang 
menekankan pada bentuk kepercayaan beraspek religius. Oleh karenanya beberapa motif batik terutama yang memiliki nilai falsafah tinggi dinyatakan sebagai motif larangan untuk dipakai masyarakat umum. Di dalam Kamus Besar Bahasa Indonesia, simbol adalah lambang yang dibuat oleh manusia sendiri sebagai media komunikasi, yang sifatnya konvensional dan arbitrary (mana suka) (Poerwadarminta, 2007). Dengan demikian sebenarnya melalui penggunan motif batik manusia dapat berkomunikasi untuk menunjukkan keberadaan dirinya, lingkungan asalnya, makna dibalik motif hiasnya, latar belakang kebudayaannya, kepercayaan, adat-istiadat, sifat dan tata kehidupan, dan dinamika kebudayaan yang mempengaruhinya.

Batik adalah salah satu hasil budaya masyarakat. Konsep tentang batik secara panjang lebar sudah diuraikan pada bagian atas. Menyitir tulisan Ahimsa-Putra (2009:24), maka dalam perspektif fenomenologi, batik harus didefinisikan sejajar dengan pandangan Husserl tentang phenomenon, yaitu sebagai suatu bentuk kesadaran (consciousness). Dengan demikian pada kesempatan ini yang mendapatkan kesadaran adalah manusianya, bukan batiknya, karena batik di sini merupakan sebuah simbol. Adapun yang dimaksud dengan manusia di sini adalah masyarakat Jawa Kuna, dia bisa sebagai pembatik atau orang yang menggunakan batik. Sebagai konsekuensi menggunakan perspektif fenomenologi, penulis akan mencoba mendefinisikan batik dalam perspektif seperti yang telah dikenalkan oleh Husserl. Semoga ada koreksi jika terjadi kesalahan.

Secara fenomenologis, batik dapat didefinisikan sebagai sebuah kesadaran mengenai (a) adanya penggunaan motif batik pada dua lapisan masyarakat, lapisan atas (bangsawan) dan lapisan bawah (rakyat kecil) dan (b) bagaimana masyarakat lapisan bawah (c) dapat menjalin hubungan simbolik dengan lapisan atas dengan motif batik itu.

Definisi di atas menekankan kesadaran masyarakat, khususnya masyarakat Jawa Kuna, tentang penggunaan batik. Secara tidak langsung, pada masyarakat Jawa Kuna, terdapat peraturan yang menetapkan adanya perbedaan motif antara rakyat kecil dengan bangsawan. Oleh karena itu, muncul kesadaran dari pembatik untuk membuat pola-pola motif tertentu untuk disesuaikan dengan siapa pemakai batik itu. Demikian pula masyarakat yang menggunakan batik, dengan kesadaran dia akan menyesuaikan dengan aturan yang telah ditetapkan oleh adat.

\section{Kesadaran tentang "lapisan atas" dan "lapisan bawah"}

Kesadaran mengenai "lapisan atas" dan "lapisan bawah" dalam suatu masyarakat adalah kesadaran mengenai lapisan sosial masyarakat, stratifikasi sosial masyarakat. Diskripsi fenomenologis mengenai stratifikasi sosial masyarakat dapat juga difokuskan pada diskripsi kesadaran individu maupun kolektif. Diskripsi dapat memusatkan perhatian pada unsur-unsur dan keadaan "lapisan atas" dan "lapisan bawah" sebagaimana diketahui, disadari, dan diyakini oleh masyarakat Jawa Kuna, baik oleh individu maupun secara jamaah.

Pada kasus upacara penetapan sima, disadari adanya dua lapisan masyarakat yang hadir. Pertama, pemberi anugerah sima, yaitu "lapisan atas" yang diwakili oleh para pejabat kerajaan; dan kedua, penerima anugerah sima, "lapisan bawah". Pada kesem- 
Makna Simbolis Batik ... - Siti Maziyah, dkk.

Tabel 1. Akibat Berubahnya Status Daerah menjadi Sima

\begin{tabular}{ll}
\hline Lapisan Masyarakat & Akibat Status Sima \\
\hline Lapisan Atas & Memberi anugerah \\
& Melepas pajak \\
& Menerima hadiah \\
Lapisan Bawah & Menerima anugerah \\
& Menerima pajak \\
& Memberi hadiah \\
\hline
\end{tabular}

patan itu, dengan penuh kesadaran karena menerima anugerah yang tak terhingga dari bangsawan, maka kemudian penerima sima sebagai rakyat kelas bawah memberikan hadiahhadiah motif batik tertentu pada upacara penetapan sima kepada para bangsawan itu. Pemberian hadiah itu berkenaan karena setelah mendapatkan status sima, maka daerah itu menjadi daerah bebas pajak. Untuk selanjutnya, pajak yang seharusnya diserahkan kepada kerajaan, pengelolaannya kemudian diserahkan kepada penerima sima. Dengan demikian, kalau menggunakan bahasa jaman sekarang, maka penerima sima itu melakukan syukuran atas anugerah penguasa pada daerah kekuasaannya. Akibat dari berubahnya status suatu daerah menjadi sima dapat digambarkan pada tabel 1 .

Selain dengan pemberian hadiah, status sebagai "lapisan atas" itu di- tunjukkan juga dengan gelar yang disandangnya. Hal ini juga disadari oleh masyarakat Jawa Kuna, demikian pula "gelar" untuk "lapisan bawah". Tabel 2 merupakan contoh gelar atau partikel penghormat (honorifik prefiks) pada masyarakat Jawa Kuna yang diketahui berdasarkan susunan pada pasek-pasek Prasasti Kayu Ãra Hiwang, 823 Ç dan Prasasti Karang Tengah, 746 Ç:.

Pada contoh di atas, gelar "lapisan atas" diwakili oleh Rakryan di Watu Tihang yang bernama Pu Sanggrãma Çurandara penduduk desa di Gulak watak Mamali deça. Gelar yang disandang oleh tokoh adalah "Rakryan" yaitu penguasa wilayah watak (raka i). Raka artinya penguasa wilayah watak, sedangkan $i$ menunjukkan daerah kekuasaannya. Untuk tokoh di atas, daerah kekuasaannya adalah di Watu Tihang, meskipun tempat tinggalnya berada di desa di Gulak watak Mamali

Tabel 2. Partikel penghormat dan hadiah yang diterima dalam upacara penetapan sima

\begin{tabular}{llll}
\hline Lapisan atas & Hadiah & Lapisan bawah & Hadiah \\
\hline Rakryan di Watu Ti- & Satu stel kain motif & Si Pingul ayahnya & sehelai kain motif \\
hang Pu Sanggrãma & gaňjar haji pãtra & Ambari & takurang \\
$\begin{array}{l}\text { Çurandara penduduk } \\
\text { desa di Gulak watak }\end{array}$ & $\begin{array}{l}\text { buah cincin prasãda } \\
\text { beratnya 1 suwarna }\end{array}$ & & \\
Mamali deça & Satu stel kain motif & Si Pamu ayahnya & sehelai kain motif \\
Pamagat Wadihati Pu & Banu & Takurang \\
$\begin{array}{l}\text { Dangpit penduduk } \\
\text { desa di Pada dan watak } \\
\text { Wadihati }\end{array}$ & $\begin{array}{l}\text { seberat 1 suwarna, 1 } \\
\text { buah cincin }\end{array}$ & & \\
& prasãda beratnya 6 & & \\
masa & Sumber: Prasasti Karang Tengah, 746 Ç \\
\hline
\end{tabular}


deça. Honorifik prefiksnya adalah "Pu", adapun nama dirinya adalah Sanggrãma Çurandara. Karena merupakan penguasa wilayah watak, maka hadiah yang diberikan kepadanya lebih elok dari pada tiga orang yang lain. "Pu" atau "empu" menunjukkan partikel penghormat yang tinggi, ditunjukkan oleh dua orang tersebut, yang satu adalah penguasa wilayah watak, sedangkan yang lain adalah pejabat kehakiman. Pamagat artinya adalah pemutus (perkara), baik perkara masalah agama atau perkara sosial masyarakat. Sementara itu, "lapisan bawah" diwakili oleh si Pingul ayahnya Ambari dan si Pamu ayahnya Banu. Kedua orang ini partikel penghormatnya adalah "si", menunjukkan bahwa kedudukannya yang rendah, hanya warga desa biasa saja, wong cilik. Informasi ini lebih dikukuhkan lagi dengan hadiah yang diperoleh hanya sehelai kain dengan motif takurang.

\section{Kesadaran tentang Komunikasi "lapisan atas" dan "lapisan bawah"}

Kelemahan data prasasti mengenai motif batik adalah hanya diketahuinya nama motifnya saja tanpa diketahui gambar motifnya seperti apa. Dengan demikian, untuk menggali simbol-simbol dalam batik, khususnya untuk berkomunikasi antara "lapisan atas" dan "lapisan bawah" menjadi kurang sempurna. Meskipun demikian, penulis mencoba untuk menggali data-data lain tentang batik selain yang berada pada pasek-pasek untuk melengkapi informasi tentang batik pada masyarakat Jawa Kuna.

Terjemahan bebas motif gaňjar haji pãtra sisi berdasarkan Kamus Jawa Kuna (Zoetmulder, 2000:275, 797,1104) adalah kain khusus hadiah untuk penguasa wilayah watak yang bermotif daun pada sisi-sisinya. Jika dilihat dari terjemahan bebasnya itu, dapat dikatakan bahwa motif kain itu dapat digunakan sebagai simbol yang dapat dipakai untuk berkomunikasi dengan masyarakat pengguna budayanya, yaitu adanya motif khusus untuk dihadiahkan (gaňjar) kepada penguasa wilayah watak yang sering disebut dengan gelar "haji" berupa motif daun (pãtra) pada bagian sisinya.

Secara singkat kita mendapat dua informasi dari motif batik ini, pertama, motif ini khusus untuk dihadiahkan kepada pejabat yang bergelar "haji"; kedua, motif kain ini, yaitu bentuk daun, tentu diilhami oleh alam lingkungan si pembatik. Hanya sayangnya kita tidak tahu persis seperti apa motif pãtra sisi itu. Motif ini banyak ditemukan pada prasasti-prasasti yang dikeluarkan oleh Mpu Sindok, Raja Kerajaan Mataram pada abad X M. Sebagian besar prasasti yang dikeluarkan oleh Mpu Sindok adalah prasasti sima, dan jika dicermati, maka jenis motif kain gaňjar haji pãtra sisi ini selalu diberikan kepada pejabat-pejabat tingkat atas saja, yang sejajar dengan Rakryan.

Sedangkan motif rangga adalah sejenis kain yang khas baik warna maupun motifnya (Zoetmulder, 2000:920). Simbol kain ini di dalam masyarakat Jawa Kuna berbeda dengan gaňjar haji pãtra sisi. Zoetmulder (2000:920 dan 1332) sudah menerjemahkan bahwa motif rangga adalah sejenis kain yang khas baik warna maupun motifnya. Akan tetapi di sini ia tidak menjelaskan lebih lanjut mengenai bentuk motif dan warnanya seperti apa. Di dalam keterangannya ada kitab susastra yang menuliskan: "... asiñjan saka lor alus rangga uni ..." (memakai kain halus dari utara yang dihiasi wuni...). Pesan yang disampaikan oleh motif batik ini juga khusus ketika kita sandingkan dengan nama jabatan pejabat yang menerimanya. Di dalam Prasasti Kayu Ara Hiwang, pejabat yang 
Makna Simbolis Batik ... - Siti Maziyah, dkk.

menerimanya adalah Pamagat Wadihati. Di atas sudah diketahui arti dari "Pamagat", yaitu pemutus perkara atau pejabat kehakiman. Sedangkan "wadihati" menurut Zoetmulder (2000:1364) berarti pejabat tinggi. Dengan demikian, memang motif kain itu hanya diperuntukkan bagi pejabat tinggi di bawah rakryan.

Takurang adalah kain yang dapat digunakan untuk membungkus badan, dengan cara dililitkan. Zoetmulder (2000:1183) tidak menjelaskan lebih lanjut bagaimana motif kain itu. Jika motif kain itu disandingkan dengan partikel penghormat si penerima, maka dapat diinterpretasikan bahwa kain motif takurang adalah kain batik yang tidak terlalu istimewa, karena "hanya" diberikan kepada warga masyarakat biasa yang mendapat sebutan "si", yaitu wong cilik.

Prasasti-prasasti pada abad $X$ yang dikeluarkan oleh Pu Sindok selalu merupakan prasasti yang panjang, demikian pula dengan daftar pejabat yang menerima hadiah dalam upacara penetapan sima. Jika dikupas satu per satu motif kain berikut pejabat yang menerimanya, maka akan dapat diketahui pola atau struktur kesadaran masyarakat Jawa Kuna di dalam menggunakan motif batik. Dengan demikian, sebenarnya melalui motif batik, masyarakat Jawa Kuna telah melakukan komunikasi antara "lapisan atas" dan "lapisan bawah". Komunikasi itu menggunakan simbol-simbol batik, yang sayangnya tidak semuanya dijumpai gambar motifnya. Sebagian dari gambar motif batik itu dapat ditemukan pada relief candi atau patung-patung tertentu yang mengenakan kain bermotif batik.

\section{SIMPULAN}

Berdasarkan pembahasan di atas, dapat disimpulkan bahwa motif batik pada masyarakat Jawa Kuna itu memiliki makna simbolik dan dapat digunakan sebagai sarana untuk berkomunikasi bagi masyarakat sezaman. Masyarakat Jawa Kuna menyadari bahwa melalui motif-motif batik dapat diketahui stratifikasi sosial masyarakat. Dengan demikian, kepandaian membatik dan menciptakan motif-motif batik itu sebenarnya dilakukan dengan sadar oleh pembatik Jawa Kuna. Demikian pula masyarakat yang menggunakannya sudah menyadari posisi dirinya dalam stratifikasi sosial masyarakat Jawa Kuna. Jika digali lebih dalam, tentu motif batik dapat digunakan untuk mendiskripsikan kondisi masyarakat Jawa Kuna yang lebih luas lagi.

\section{DAFTAR PUSTAKA}

Ahimsa-Putra, Heddy Shri, 2009, "Fenomenologi Agama: Pendekatan Fenomenologi Untuk Memahami Agama", Jurnal Penelitian Walisongo, Vol. XVII, No. 2, Nopember, hlm. 133.

Puslitbang Arkenas, 2008, Metode Penelitian Arkeologi, Cetakan kedua, Jakarta: Pusat Penelitian dan Pengembangan Arkeologi Nasional.

Boechari, 1977, "Epigrafi dan Sejarah Indonesia", Majalah Arkeologi, Th. I, No. 2, Jakarta: Lembaga Arkeologi Fakultas Sastra Universitas Indonesia.

Brandes, J., 1889, “Een Jayapatra of Acte van eene Rechterlijke Uitspraak van Çaka 849", TBG, XXXII, hlm. 98-149.

Brandes, J.L.A. , 1913, “Oud-Javaansche Orkonden Negalaten Transcripties van Wijlen Dr. J.L.A. Brandes Uitgegeven door N.J. Krom", VBG, LX.

Doellah, Santosa, 2002, Batik: Pengaruh Zaman dan Lingkungan, Surakarta: Danar Hadi. 
Hamzuri, 1981, Batik Klasik, Jakarta: Djambatan.

Djumena, Nian S., 1990, Batik dan Mitra, Jakarta: Djambatan.

Koentjaraningrat, 1990, Pengantar Ilmu Antropologi, Jakarta: PT Rineka Cipta.

Maziyah, Siti, 1992, "Pembatasan Usaha Perdagangan di Daerah Sîma Pada Abad X Masehi, Tinjauan Berdasarkan Kedudukan Daerah Sîma", Skripsi pada Jurusan Arkeologi, Yogyakarta: Fakultas Sastra Universitas Gadjah Mada.

2004, "Peran Perempuan Dalam Sektor Perdagangan dan Industri Batik di Yogyakarta Tahun 1900-1965", Laporan Penelitian, Lembaga Penelitian Universitas Diponegoro: Penelitian Studi Kajian Wanita.

Poerwadarminta, 2007, Kamus Besar Bahasa Indonesia, Jakarta: Gramedia.

Poesponegoro, Marwati Djoened, 1993, Sejarah Nasional Indonesia II: Jaman Kuna, ed. Bambang Sumadio, Cetakan kedelapan, Jakarta: Balai Pustaka.

Prasodjo, Tjahjono, 1987, “Prasasti Peradi- lan: Analisis Strutural dan Tinjauan Pelaksanaan Hukum Jawa Kuna", Skripsi pada Jurusan Arkeologi, Yogyakarta: Fakultas Sastra Universitas Gadjah Mada.

Suyono, Ariyono dan Aminuddin Siregar, 1985, Kamus Antropologi, Edisi pertama, Cetakan pertama, Jakarta: Akademika Pressindo.

Soekmono, 1993, Pengantar Sejarah Kebudayaan Indonesia 2, Cetakan ke sembilan, Yogyakarta: Kanisius.

Susanto, S.K. Sewan, 1973, Seni Kerajinan Batik Indonesia, Jakarta: Balai Penelitian Batik dan Kerajinan, Lembaga Penelitian dan Pendidikan Industri, Departemen Perindustrian R.I.

Tim Penyusun Kamus Pusat Pembinaan dan Pengembangan Bahasa, 1996, Kamus Besar Bahasa Indonesia, Edisi kedua, Jakarta: Balai Pustaka.

Zoetmulder, P.J. , 2000, Kamus Jawa KunaIndonesia, Penerjemah: Darusuprapta dan Sumarti Suprayitna, Jakarta: Gramedia Pustaka Utama. 